\title{
Analgesic, anti-inflammatory and antimicrobial effects of ethanol extracts of mango leaves
}

\author{
M. R. Islam, M. A. Mannan ${ }^{1}$, M. H. B. Kabir ${ }^{1}$, A. Islam ${ }^{2}$ and K. J. Olival ${ }^{2}$ \\ Pharmacologist, Bangladesh Council of Scientific and Industrial Research (BCSIR), ${ }^{1}$ Microbiologist, Chittagong \\ Veterinary and Animal Sciences University (CVASU) and ${ }^{2}$ Conservation Medicine Programme, Ecohealth Alliance \\ 460 West 34th St, New York, NY 10001, USA
}

\begin{abstract}
The present study was carried out to investigate the analgesic, anti-inflammatory, antibacterial and antifungal properties of ethanol leave extract of Mangifera indica. For evaluation of analgesic and anti-inflammatory properties, acetic acid induced writhing response model and carrageenan induced paw edema model were used in Swiss albino mice and Wistar albino rats, respectively. In both cases, leaves extract were administered and the obtained effects were compared with commercially available analgesic and anti-inflammatory drug, Diclofenac Sodium. In analgesic bioassay, oral administration of the ethanol leaves extract significantly $(P<0.01)$ reduced the writhing response. The degree of inhibition of leaves extract was $55.8 \%$ compared to the effect of standard analgesic drug, Diclofenac Sodium (75.28\%). On the other hand, though leaves extract reduce paw edema but they did not show any significant effect. The antibacterial and antifungal activity of leaves extract also carried out by disc diffusion technique and poisoned food technique. In antibacterial experiment, leaves extract showed $7.0 \mathrm{~mm}$ to $11.5 \mathrm{~mm}$ in diameter of zone of inhibition against six Gram positive bacteria (such as Staphylococcus aureus, Streptococcus agalactiae, Bacillus cereus, Bacillus megaterium, Bacillus subtilis and Lactobacillus vulgaricus) and two Gram negative bacteria (such as Shigella flexneri and Shigella sonei ). But Salmonella typhi and Proteus sp had negative activity on leaves extract. The leaves extract of Mangifera indica showed antifungal activity against three fungal species (such as Aspergillus ustus, Aspergillus niger and Aspergillus ochraceus).
\end{abstract}

Keywords: Mangifera indica, Analgesic, Anti-inflammatory, Antibacterial, Antifungal

\section{Introduction}

Bangladesh owing to its favorable climatic influences has been blessed with immense natural resources including explored and unexplored herbal medicinal plants. About 5000 species of phanerogams and pteridophytes grow in Bangladesh. More than a thousand of these have been claimed to possess medicinal or curative properties. Recently, 546 species have been identified as having medicinal properties and therapeutic use (Ghani, 1998). Medicinal plants are the great importance to the health of individual and communities. The medicinal values of those plants possess some chemical active substances that produce a definite physiological action on the human body and animal health. The most important bioactive substances are alkaloid, tannin, flavonoid and phenolic compounds (Edeogra, 2005). Drugs which are used presently for the management of pain and inflammatory conditions are either steroidal like corticosteroids or non steroidal like aspirin. All of these drugs possess more or less side and toxic effects like renal failure, allergic reactions, hearing loss or they may increase the risk of hemorrhage by affecting platelet function (Thomas, 2000). Moreover, synthetic drugs are very expensive (Ahmad et al. 1992). On the contrary, many plant origin drugs had been used since long time without any adverse effects. The use of medicinal plants as herbal remedies to prevent and cure several ailments differs from community to community (Sharif and Banik, 2006). Plants are the cheapest and safer alternative sources of antimicrobials (Doughari et al., 2007). In Bangladesh, very few works have been done to explore the possibilities of utilizing the local herbs and shrubs in veterinary practice. Therefore, the present research has been designed to investigate the analgesic, anti-inflammatory and antimicrobial effects of leaves extract of Mangifera indica (Mango) available in Bangladesh. 


\section{Materials and Methods}

\section{Sample collection}

The leaves of Mangifera indica was collected from Barisal, Chittagong and Mymensingh district of Bangladesh. The plant was taxonomically identified by a Taxonomist, Industrial Botany Research Division, Bangladesh Council of Scientific and Industrial Research (BCSIR) Laboratories, Chittagong. All the research work was carried out according to the guidelines of Institutional Animal Ethics Committee (IAEC), BCSIR.

\section{Preparation of plant extract}

The fresh leaves of Mangifera indica were washed with water immediately after collection. The collected leaves were chopped into small pieces, air dried at room temperature for about 10 days and ground into powder form and stored in an airtight container. $650 \mathrm{gm}$ powder was macerated in 5 litre pure methanol for 7 days at room temperature with occasional stirring. After 7 days, methanol extract was filtered off through cotton plug and finally with a Whatman no. 1 filter paper. The extract was concentrated under reduced pressure below $50^{\circ} \mathrm{C}$ temperature through rotatory vacoum evaporator. The concentrated extracts were collected in a Petri dish and allowed it to air dry for complete evaporation of methanol. The whole process was repeated three times and finally, $45 \mathrm{gm}, 50 \mathrm{gm}$ and $55 \mathrm{gm}$ greenish colored concentrated leaves extract was obtained (yield $5.3 \% \mathrm{w} / \mathrm{w}$ ) which was kept in refrigerator at $4^{\circ} \mathrm{C}$.

\section{Experimental animals and diets}

Swiss albino mice of both sexes weighing between $25 \mathrm{gm}$ and $30 \mathrm{gm}$ and Wistar Albino rats of either sex weighing between $150 \mathrm{gm}$ and $200 \mathrm{gm}$ were taken from animal house of BCSIR laboratories, Chittagong. The animals were acclimatized to room temperature $\left(28 \pm 5^{\circ} \mathrm{C}\right)$ with a relative humidity of $55 \pm 5 \%$ in a standard wire meshed plastic cages for 4 to 5 days prior to commencement of the experiment. During the entire period of study the animals were supplied with standard pellet diet and adlibitum water.

\section{Screening of analgesic activity of plant extract}

Acetic acid induced writhing test model as described by Koster et al. (1959) was performed to evaluate the antinocipeptive activities of Mangifera indica leaves extracts. $1 \%(\mathrm{v} / \mathrm{v})$ acetic acid solution, $2 \mathrm{mg} / \mathrm{ml}$ Diclofenac Sodium, $200 \mathrm{mg} / \mathrm{ml}$ Mangifera indica, and fifteen (15) Swiss Albino mice with average body weight of $25 \mathrm{gm}$ to $30 \mathrm{gm}$ and 3 months of age in both sexes were taken during experiment. Finally, percentage (\%) analgesic activity was calculated using the following formula-

$$
\% \text { analgesic activity }=\frac{\text { Mean writhing count }(\text { Control group }- \text { Treated group })}{\text { Mean writhing count of control group }} \times 100
$$

\section{Assay of anti-inflammatory activity of plant extract}

Carrageenan induced paw edema model described by (Olajide et al., 2000) was used for evaluating potential Mangifera indica leaves extract on inflammation. $1 \% \mathrm{w} / \mathrm{v}$ carrageenan, $200 \mathrm{mg} / \mathrm{ml}$ Mangifera indica leaves extract solution, $2 \mathrm{mg} / \mathrm{ml}$ Diclofenac Sodium, Fifteen Wistar Albino Rats and Plethesmometer were listed for this assay. The inhibitory activity was calculated according to the following formula -

$$
\% \text { inhibition }(\mathrm{I})=\frac{(\mathrm{Ct}-\mathrm{Co}) \text { control }-(\mathrm{Ct}-\mathrm{Co}) \text { treated }}{(\mathrm{Ct}-\mathrm{Co}) \text { control }} \times 100
$$


Where $\mathrm{Ct}$ is the right hind paw thickness volume (in $\mathrm{mm}^{3}$ ) at time $\mathrm{t}$, Co is the right hind paw thickness volume (in $\mathrm{mm}^{3}$ ) before carrageenan injection, $\mathrm{Ct}$-Co is paw edema, $(\mathrm{Ct}-\mathrm{Co}$ ) control is edema or paw size after carrageenan injection to control rats at time t. (Ct - Co) treated is edema or paw size after carrageenan injection to treated rats at time t.

\section{Antimicrobial screening}

\section{a) Test organisms}

10 bacteria and 4 fungi were used as test organisms to screen the anti-microbial activity of leaves extracts. 6 were Gram positive and 4 were Gram negative among the 10 bacteria. Bacterial and fungal cultures were collected from Nutrition and Food Science Institute of Dhaka University.

\section{b) Antibacterial activity}

\section{Disc diffusion methods}

The disc diffusion technique (Bauer et al, 1996) is a widely accepted in vitro investigation for primary screening of agents which may possess any antibacterial activity. It is a qualitative or quantitative test indicating the sensitivity or resistance of the microorganism to the test materials. Mueller-Hinton agar media was considered to be the best for routine susceptibility testing of non-fastidious bacteria.

\section{c) Antifungal activity}

\section{Poisoned food methods}

The poisoned food technique (Grover and Moore, 1962) was used to screen the anti-fungal activity of the herbal products. Potato dextrose agar was used as a culture medium. The percentage inhibition of mycelial growth of the test fungus was calculated by the following formula:

$\%$ inhibition $(I)=\frac{\text { Diameter of the fungal colony in } C-\text { Diameter of the fungal colony in } T}{\text { Diameter of the fungal colony in } C} \times 100$

Here, $\mathrm{C}=$ control group, $\mathrm{T}=$ treatment group.

\section{Statistical analysis}

The results were presented as the Mean \pm SEM (Standard Error) and statistical significance between the groups was determined by means of one-way analysis of variance (ANOVA) followed by unpaired Student's $t$-test to determine statistical significance. SPSS for WINDOWS ${ }^{\circledR T M}$ was applied for analysis of data. Probability $(P)$ value of 0.05 or less $(P \leq 0.05)$ was considered as significant.

\section{Results and Discussion}

\section{Analgesic activity}

When $1 \%(\mathrm{v} / \mathrm{v})$ acetic acid solution ( $3.3 \mathrm{ml} / \mathrm{kg}$ body weight) was injected intraperitoneally in mice, the control animal showed $66.75 \pm 2.28$ writhing count / 20 minutes. Diclofenac Sodium caused significant reduction of writhing count from $66.75 \pm 2.28$ to $16.5 \pm 1.71 / 20$ minutes. On the other hand, Mangifera indica leaves extract reduced the writhing count from $66.75 \pm 2.28$ to $29.5 \pm 2.72 / 20$ minutes. Mangifera indica and Diclofenac Sodium showed significant $(\mathrm{P}<0.01)$ reduction of pain in comparison with control group (Table 1). 
Table 1. Effect of leaves extract of Mangifera indica and Diclofenac Sodium on acetic acid induced writhing response in Swiss albino mice

\begin{tabular}{|c|c|c|c|c|}
\hline Group & Treatment & Dose & Writhing count & $\%$ Activity \\
\hline Control & Distilled water & $2 \mathrm{ml}$ & $66.75 \pm 2.28$ & - \\
\hline Positive control & Diclofenac Sodium & $40 \mathrm{mg} / \mathrm{kg}$ & $16.5 \pm 1.71$ & $75.28 \%$ \\
\hline Treated & Mangifera indica extract & $2 \mathrm{gm} / \mathrm{kg}$ & $29.5 \pm 2.72$ & $55.8 \%$ \\
\hline
\end{tabular}

Myorelaxant, anti-inflammatory substances (Koyama et al., 1997) and opoid such as codeine (Aydin et al., 1999) were able to reduced pain produced by acetic acid. Therefore, it was suggested that the inhibition of prostaglandin synthesis was remarkably efficient as an anti-nociceptive mechanism in visceral pain (Franzotti et al., 2002). Since leaves extract of Mangifera indica (2 gm/ $\mathrm{kg}$ ) showed significant inhibition $(P<0.01)$ of acetic acid induced writhing response of mice, so it could be suggested that Mangifera indica leaves extract had potential analgesic activity.

\section{Anti-inflammatory activity}

Anti-inflammatory activity of Mangifera indica leaves extract was assessed and showed in Table 2. Diclofenac Sodium produced $38.7 \%, 45.67 \%, 58.32 \%$ and $60.88 \%$ anti-inflammatory effect at 1 st hour, 2nd hour, 3rd hour and 4th hour after carrageenan injection, respectively.

Table 2. Effect of leaves extract of Mangifera indica and Diclofenac Sodium on carrageenan induced paw edema Wistar albino rat

\begin{tabular}{|c|c|c|c|c|c|c|c|c|c|c|}
\hline \multirow[t]{2}{*}{ Group } & \multirow[t]{2}{*}{ Treatment } & \multirow[t]{2}{*}{ Dose } & \multicolumn{4}{|c|}{ Paw edema $\left(\mathrm{mm}^{3}\right)$} & \multicolumn{4}{|c|}{$\%$ Inhibition } \\
\hline & & & 1st hr & 2nd hr & $3 \mathrm{rd} \mathrm{hr}$ & 4th $\mathrm{hr}$ & 1st hr & 2nd hr & $3 \mathrm{rd} \mathrm{hr}$ & 4th $\mathrm{hr}$ \\
\hline Control & $\begin{array}{c}\text { Distilled } \\
\text { Water }\end{array}$ & $2 \mathrm{ml}$ & $\begin{array}{c}0.372 \pm \\
0.048\end{array}$ & $\begin{array}{c}0.635 \pm \\
0.057\end{array}$ & $\begin{array}{c}0.763 \pm \\
0.069\end{array}$ & $\begin{array}{c}0.882 \pm \\
0.111\end{array}$ & - & $\begin{array}{l}- \\
-\end{array}$ & - & - \\
\hline $\begin{array}{l}\text { Positive } \\
\text { Control }\end{array}$ & $\begin{array}{l}\text { Diclofenac } \\
\text { Sodium }\end{array}$ & $\begin{array}{c}40 \\
\mathrm{mg} / \mathrm{kg}\end{array}$ & $\begin{array}{c}0.228 \pm \\
0.041\end{array}$ & $\begin{array}{c}0.345 \pm \\
0.071\end{array}$ & $\begin{array}{c}0.318 \pm \\
0.030\end{array}$ & $\begin{array}{c}0.345 \pm \\
0.044\end{array}$ & $38.7 \%$ & $45.67 \%$ & $58.32 \%$ & $60.88 \%$ \\
\hline Treated & $\begin{array}{c}\text { Leaves } \\
\text { extract of } \\
\text { Mangifera } \\
\text { indica }\end{array}$ & $\begin{array}{c}2 \\
\mathrm{gm} / \mathrm{kg}\end{array}$ & $\begin{array}{c}0.244 \pm \\
0.043\end{array}$ & $\begin{array}{c}0.390 \pm \\
0.060\end{array}$ & $\begin{array}{c}0.486 \pm \\
0.061\end{array}$ & $\begin{array}{c}0.628 \pm \\
0.050\end{array}$ & $21.0 \%$ & $34.4 \%$ & $36.3 \%$ & $28.7 \%$ \\
\hline
\end{tabular}

The Mangifera indica leaves extract produced $21.0 \%, 34.4 \%, 36.4 \%$ and $28.7 \%$ effect at 1 st hour, 2 nd hour, 3rd hour and 4th hour after carrageenan injection respectively. Development of edema in the paw of rat after injection of carrageenen was a biphasic event (Vinger et al., 1969). This study had showed the leaves extract of Mangifera indica possessed no significant anti-edematogenic effect compared to Diclofenac Sodium on paw edema in rats. The result of the study indicated that probably Mangifera indica had no significant anti-inflammatory activity.

\section{Antimicrobial activity}

Antibacterial activity of Mangifera indica leaves extract was found moderate activity against Gram positive bacteria and poor activity against Gram negative bacteria. More specifically Mangifera indica leaves extract showed $7.0 \mathrm{~mm}, 7.5 \mathrm{~mm}, 11.5 \mathrm{~mm}, 8.5 \mathrm{~mm}, 9.0 \mathrm{~mm}$ and $9.5 \mathrm{~mm}$ in diameter of zone of inhibition against six Gram positive bacteria like Staphylococcus aureus, Streptococcus agalactiae, Bacillus cereus, Bacillus megaterium, Bacillus subtilis and Lactobacillus vulgaricus, respectively and $9.5 \mathrm{~mm}$ and $9.5 \mathrm{~mm}$ in diameter of zone of inhibition was observed against two Gram negative bacteria like Shigella flexneri and Shigella sonnei but no activity was observed against Salmonella typhi and Proteus sp. On the other hand, standard antibiotic, tetracycline $(30 \mu \mathrm{g} / \mathrm{disc})$ showed significant antibacterial activity against all tested bacteria (Table 3). The bioactive component, mangiferin isolated from Mangifera indica was reported to possess remarkable anti-influenza activity (Neon, 1984). Some of this compound had been reported to possess antibacterial activity (Dweck, 2001). This result indicated that the leaves extract of Mangifera indica possessed certain phytochemicals which had moderate activity against Gram positive bacteria and low activity against Gram negative bacteria. 
Table 3. Anti-bacterial activity of leaves extract of Mangifera indica and Tetracycline

\begin{tabular}{|c|c|c|c|}
\hline Types of the Bacteria & Name of the Bacteria & $\begin{array}{c}\text { Tetracycline } \\
(30 \mu \mathrm{g} / \mathrm{disc})\end{array}$ & $\begin{array}{c}\text { Mangifera indica } \\
\text { (5mg/disc) }\end{array}$ \\
\hline \multirow{3}{*}{ Gram positive } & Staphylococcus aureus & 12.5 & 7.0 \\
\cline { 2 - 4 } & Streptococcus agalactiae & 22.0 & 7.5 \\
\cline { 2 - 4 } & Bacillus cereus & 19.5 & 11.5 \\
\cline { 2 - 4 } & Bacillus megaterium & 7.0 & 8.5 \\
\cline { 2 - 4 } & Bacillus subtilis & 20.0 & 9.0 \\
\cline { 2 - 4 } & Lactobacillus vulgaricus & 11.5 & 9.5 \\
\hline \multirow{7}{*}{ Gram negative } & Salmonella typhi & 14.5 & - \\
\cline { 2 - 4 } & Shigella flexneri & 23.0 & 9.5 \\
\cline { 2 - 4 } & Shigella sonei & 22.5 & 9.5 \\
\cline { 2 - 4 } & Proteus $s p$ & 11.0 & - \\
\hline
\end{tabular}

Table 4. Anti-fungal activity of leaves extract of Mangifera indica

\begin{tabular}{|c|c|}
\hline Name of the fungus & Percentage of inhibition (\%) \\
\hline Aspergillus ustus & 29 \\
\hline Aspergillus niger & 21 \\
\hline Aspergillus ochraceus & 19 \\
\hline
\end{tabular}

Mangifera indica leaves extracts showed antifungal activity that was satisfactory. Leaves extract $(4 \mathrm{mg} / 20 \mathrm{ml})$ of Mangifera indica showed a prominent significant degree of anti-fungal activity (Table 4$)$ against Aspergillus ustus (29\%), Aspergillus niger (21\%) and Aspergillus ochraceus (19\%).

In a word, the resistance of the various types of organisms increased due to indiscriminate use of commercial anti-microbial drugs (WHO, 2002). This situation forced the researchers to search the new anti-microbial substances from different sources including medicinal plant and leaves extract of Mangifera indica might be considered as effective herbal drugs against pain, inflammation, bacterial infection and some fungal infection. Further investigation was required for isolation, identification and characterization of different active compounds of leaves extract, their mode of action and therapeutic ranges.

\section{References}

Ahmad, F., Khan, R.A. and Rasheed, S. 1992. Study of analgesic and anti-inflammatory activity from plant extracts of Lactuca scariola and Artemisia absinthium. Journal of Islamia Academy Sciences. 5: 111-114.

Aydin, S., Demir, T., Otzuk, Y. and Baser, K.H.C. 1999. Analgesic activity of Nepeta. Italic Phytother Drugs. 13: 20-23.

Bauer, A.W., Kirby, W.M., Sherris, J.C. and Turck, M. 1996. Antibiotic susceptibility testing by standardized single disc method. American Journal of Clinical Pathology. 44: 493-496.

Doughari, J.H., El-mahmood, A.M. and Manzara, S. 2007. Studies on the antibacterial activity of root extracts of Carica papaya L. African Journal of Microbiology. 037- 041.

Dweck, A.C. 2001. Article for cosmetics \& toiletries magazine ethnobotanicalplants from Africa. Black Medicare Limited.

Edeoga, H.O. 2005. Phytochemical constituents of some Nigerian Medicinal plants. African Journal of Biotechnology. 4(7): 85-688.

Franzotti, E.M., Santos, C.V., Rodrigues, H.M., Mourao, R.H., Andrade, M.R. and Antoniolli, A.R. 2002. Anti-inflammatory, analgesic and acute toxicity of Sida cadifolia L. Journal Ethnopharmacology 72: 273-278.

Ghani, A. 1998. Medicinal Plants of Bangladesh: Chemical Constituents and Uses. (Asiatic Society of Bangladesh, Dhaka).

Grover, R.K .and Moore, J.D. 1962. Sclerotinia fructicola and S. laxa. Phytopathology. 52:876 - 880.

Koyama, K., Imaizumi, T. and Akiba, M. 1997. Antinociceptive components of Ganoderma lucidum Planta Medicina. 63: $224-227$. 
Koster, R., Anderson, M. and Beer, E.J. 1959. Acetic acid for analgesic screening. 18- 412.

Neon, B. 1984. Medicinal plants in Nigeria. Private Nigerian Collage Arts Sciences Technology. 1-84.

Olajide, B., Giller, K., Teucher, T., Behnke, B. and Schmitz, H. 2000. Anti-inflammatory effect of Urtica dioica extract in comparison to caffeic malic acid. Arzneimittelforschung, 46: 52-56.

Sharif, M.D.M. and Banik, G.R. 2006. Status and Utilization of Medicinal Plants in Rangamati of Bangladesh. Journal of Agricultural Science and Biology. 2(6): 268-273.

Thomas, M.C. 2000. Diuretics, ACE inhibitors and NSAIDs - the triple whammy. Medical Journal of Australia.172:184-185.

Vinegar, R., Schreiber, W. and Hugo, R. 1969. Biphasic development of carrageenan edema in rats. Journal of Pharmacotherapy. 166, 96-103.

WHO (World Health Organization). 2002. WHO launches the first global strategy on traditional medicine. Press release WHO/38. 